\title{
Inheritance Rights of Children in Customary Law and Civil Law
}

\author{
Lily Kalyana ${ }^{1}$, Evita Isretno Israhadi ${ }^{2}$ \\ $\left\{\right.$ lilykalyana@yahoo.com¹, evita_isretno@borobudur.ac.id $\left.{ }^{2}\right\}$ \\ Universitas Borobudur, Jakarta, Indonesia ${ }^{1,2}$
}

\begin{abstract}
This paper analyzes the inheritance rights of children from the perspective of customary law and civil law. Through a qualitative approach and normative juridical research methods with data collection tools using literature studies, it was found that there were differences in the application of children's inheritance rights. Customary law only recognizes equal rights that lie in descent, while civil law recognizes the difference between the inheritance rights of children based on legal children resulting from marriage and children outside marriage. This difference needs to be responded to in implementing children's inheritance rights when dealing with customary areas.
\end{abstract}

Keywords: Child; Inheritance Rights; Customary Law; Civil Law

\section{Introduction}

One of the natures given by God Almighty to humans is to reproduce/pass on offspring. The desire to continue offspring is in every human being. Therefore, humans try to find a partner to form a happy, eternal family based on God Almighty, where one of the goals of family life is to continue offspring. God often gives the gift of happiness to household couples in the form of offspring, but not all family couples are not blessed with biological offspring.[1] On the other hand, many children need protection either psychologically or economically or need both psychologically and economically. Usually, children who need psychological safeguards are born out of wedlock, while children who need economic protection are born to parents who are not economically capable as for those who need psychological and financial security, namely children who have lost their families due to being victims of war or natural disasters so that the institution of child adoption or adoption is one of the efforts that can be done to complement the happiness of families who do not have children or to provide protection for children who need it.

Indonesian society is a pluralistic society consisting of various kinds of indigenous peoples, various kinds of hereditary communities, as well as various religious adherents so that in Indonesia there are still several civil law systems that apply in Indonesia, including the western civil law system, the customary civil law system, the Islamic civil law system, and the National civil law system. In connection with the above, provisions concerning children's inheritance rights can be found in several civil law systems. It is including the provisions on children's customary inheritance rights that can be found in customary civil law systems, children's inheritance rights in national law, and in custom.[2] 
Inheritance Customary Law shows the distinctive features of traditional Indonesian schools of thought. Inheritance Customary Law is based on principles that arise from the communal and concrete schools of thought of the Indonesian nation. Therefore, the customary law of inheritance shows a principal difference with the western inheritance law. Inheritance customary law is closely related to the familial characteristics of the legal community concerned, along with their influence on the assets left behind and residing in the community; Inheritance customary law is also affected not only by social changes; the strengthening of family ties; and external influences. But their application in society (still respected) does not diminish; even in certain environments concerning the inheritance of deceased persons, customary law of inheritance is still applied as a reference in the distribution of the legacy left behind.[3]

In the civil law of inheritance, according to the Civil Code, children who are born or raised during a legal marriage are legitimate. Having the position of inheritance rights, children outside of marriage only have civil relations with their mothers and their mother's families, do not have inheritance rights. The position of children according to customary law, as biological children, has the foremost position in every indigenous people. Here arises a principal difference between the customary law of inheritance and civil law. Inheritance property may not be forced to be divided between the heirs (customary inheritance law), there is an absolute right of each heir to claim his share of the inheritance (civil rights of inheritance), and each heir can demand the distribution of legacy at any time. This paper wants to explain inheritance rights from the point of view of civil law and customary law.

\section{Method}

This research is normative juridical research, namely research conducted by examining library materials or secondary data of a legal nature,[4] with a comparative legal approach method. The comparative law approach is a study that uses two or more legal systems to compare what are the similarities and differences.[5] With this method, it is hoped to find the answers to the research questions as formulated above.

\section{Discussion}

In the understanding of parents in general, a child is seen as the successor of his generation, the child is also seen as a place where all the hopes of parents in the future must be shed and are seen as protectors of their parents when the parents are no longer physically able to earn their living[6] Children are expected as a substitute or successor of the family in terms of breadwinners and as protectors of the family. Since the child is still in the womb until he was born and even later in his further growth in indigenous peoples, there can be many traditional ceremonies that are naturally and magically religious, and which are held sequentially following the child's physical growth. All of which are aimed to protect the child and the mother who bears him from all dangers and disturbances, and later after the child is born so that the child can transform into a child who can fulfill his parents' expectations.

A child born in a legal marriage between a man and a woman has as the mother of the woman who gave birth to him and as the father of the man and the woman in question. It is an ordinary thing. In this case, not all regions have the same view. In Mentawai, Timor, Minahasa, and Ambon, for example, the woman who gave birth to the child was considered 
the mother of the child in question. So it is a typical occurrence for a woman to give birth to children in her legal marriage. In some other areas, there is an opinion that it is obligatory to denounce unmarried mothers and their children. They were often banished from the fellowship (it means that they were no longer recognized as members of the fraternity), sometimes they were even killed or, as in the previous kingdoms, they were offered to the king as slaves.[7]

The way of living together (collectively) according to the view of customary law is different when compared to western law which is more individual in nature. Customary law places more attention on togetherness while western law places more emphasis on individual rights. Koesnoe distinguishes the two laws by saying that: "Customary law puts more emphasis on what is called pandum (gifts), ngaduh (Javanese) means borrowing property (land or livestock) and then dividing the proceeds with the owner) and ngaduh (borrowing property (land or livestock) to then share the results with other property owners) while Western Law in its juridical processing will enhance emphasis on subjective rights issues with the freedom to control and enjoy them for the individual concerned.[8] Article 1066 paragraph (1) KUH Pdt states that: "No one who has a share in the inheritance is obliged to accept the continuation of the inheritance in an undivided state." This article reflects the individualistic nature of property ownership; inheritance must be divided equally. The individualistic nature of the article is strengthened by paragraph (2) that gives the right to sue the heirs against efforts so that the inheritance is not divided.

Customary inheritance law has a different character. Indonesian customary law is seen more as a process of continuous transfer and transfer of all material and immaterial wealth from one generation to another.[3] So there is the concept of collective ownership (i.e generation) of inheritance which, for the generation advantage, is not shared. The joint property ownership concept is interpreted in quite detail. Soekanto stated that in customary law there are three forms of joint property ownership, namely inheritance, extended family property, inner family property, and joint community property. Soekanto explained that heirlooms are not distributed.[9] The assets of the extended family (familliegoederen) and the nuclear family (families consisting of father, mother, and unmarried children) (beschikkingsrecht) wealth are distinguished in terms of the presence or absence of offspring. If there are no descendants, the property will be returned to the family, then the family property will return to the extended family, while the inner family property will be given to the widow/widower. Goods or joint property are assets that are included in the customary rights (beshikkingsrecht) of the legal community concerned.

The concept of property rights in customary law, which is more collective in nature, is different from the concept of property rights in western regulation. The concept of property rights according to western law, which is individualistic,[10] reflected by Article 570 of the Civil Code Pdt. The article states that: "Property rights are the right to enjoy the use of an object freely, and to act freely on the object with full sovereignty, as long as it is not guilty of a law or general regulation stipulated by a power that has the right to stipulate it, and not interfere with the rights of others; all of this without reducing the possibility of the revocation of the right in the public interest based on the provisions of the law and with the payment of compensation." Viewed from the "party" in an agreement, it can be said that in western civil law, namely the Indonesian Civil Code, a person is dealing with another person about an object that is the object of a legal relationship built in a contract. The freedom of one party to treat the object of the agreement is absolute as long as it does not harm the other party, as long as it does not conflict or harm the public interest. Even if the public interest requires the reduction or revocation of the party interest, then there must be compensation. 
To know the rights of each heir to a certain part of the inheritance, the part of the inheritance according to the provisions of the law ("wettelijk erf-deel" or "legitieme portie" articles 913 to 929). The traditional view of inheritance: Inheritance assets can be indivisible, or the implementation of the distribution is delayed for a long time or only partially divided. In customary law, inheritance recognizes giving to an adopted child, the right to a living from the inheritance of his adoptive parents, and is known as an inheritance replacement system.

Inheritance customary law is closely related to the familial characteristics of the legal community concerned and their effect on the assets left behind and in the community. Apart from that, the customary law of inheritance is also affected not only by social changes, for example, due to the strengthening of the "somah" family relationship and the weakening of ties and kinship, but also by similar foreign legal regulations which religious judges always use applied in concrete even though the effect is minuscule.

Customary law of inheritance views the rights of the child's inheritance as seen in the customary inheritance system[11] as follows :

a. Individual inheritance system. The characteristics of the legacy property can be shared among the heirs as in the bilateral society in Java.

b. The system of collective inheritance. The characteristics of the inheritance property are inherited by a group of heirs who together are a kind of legal body where the property is called inheritance, can not be divided ownership among the heirs in question and can only be distributed for use only to them (only have the right to use only), as in the matrilineal society in Minangkabau.

c. Majority Inheritance System Characteristics of an inherited property in whole or in part (several principal assets from one family) by one child only, as in Bali where there is a majority right of the oldest son and in Tanah Semenda in South Sumatra where there is a majority right of a child the oldest woman.

These three systems of heritage, each does not directly point to a particular form of community order where the system of inheritance utilizes, because a system mentioned above can be found in various types of a community order, or one form of community order can also be found in more than one inheritance system as referred to above.

Civil law in positive law in Indonesia views the position of children's inheritance rights to the inheritance of the heirs can be obtained from the class level (legitimate children; children out of wedlock; adopted children) related to the family of the heir (who died). Here the position, inheritance rights of legitimate children are not at issue; however, children outside of marriage are widely studied from various perspectives (children out of wedlock; adopted children; adopted children).

\section{Conclusion}

The existence of the position of children's inheritance rights in customary law and civil law in Indonesia is a crucial part of heirs. From the three regulations mentioned above, the degree/level of child status is decisive because there are legitimate children, stepchildren, children resulting from adultery; adopted children; children out of wedlock. It is what determines the position of the child's inheritance rights.

\section{References}


[1] A. Gosita, Masalah Perlindungan Anak. Jakarta: Akademi Presindo, 1989.

[2] K. Warman, " Map of Legislation concerning Recognition of Rights of Indigenous and Indigenous Peoples,” 2012.

[3] H. Andy, Hukum Waris. Surabaya: L.J, 2015.

[4] J. Ibrahim, “Normative Legal Research Theories and Methods," Bayu Media, Malang, 2006.

[5] D. L. Sonata, “ NORMATIVE AND EMPIRICAL LEGAL RESEARCH METHODS: DIFFERENT CHARACTERISTICS OF LEGAL RESEARCH METHODS,” FIAT JUSTISIAJurnal Ilmu Huk., 2015, doi: 10.25041/fiatjustisia.v8no1.283.

[6] H. Hartono, "Konsep Pembinaan Anak Dalam Lembaga Pembinaan Khusus Anak (LPKA) Dalam Perspektif Hak Asasi Manusia," Yuriska J. Ilm. Huk., vol. 11, no. 1, p. 74, 2019, doi: 10.24903/yrs.v11i1.458.

[7] R. Simarmata, Pengakuan Hukum Terhadap Masyarakat Adat di Indonesia. Jakarta: UNDP, 2006.

[8] S. S. Nugroho, Pengantar Hukum Adat Indonesia, terjemahan Soehardi. Solo: Pustaka Iltizam, 2016.

[9] S. Soekanto, Meninjau Hukum Adat Indonesia. Suatu Pengantar Untuk Mempelajari Hukum Adat. Jakarta: Rajawali Press, 2001.

[10] M. Fuady, Konsep Hukum Perdata. Jakarta: PT. RajaGrafindo Persada, 2016.

[11] D. Sumanto, "Hukum Adat Di Indonesia Perspektif Sosiologi Dan Antropologi Hukum Islam," JURIS (Jurnal Ilm. Syariah), vol. 17, no. 2, p. 181, 2018, doi: 10.31958/juris.v17i2.1163. 